\title{
Did Board of Directors Have an Impact on MENA Bank Performance?
}

\author{
Rim Boussaada $^{1} \&$ Majdi Karmani ${ }^{2}$ \\ ${ }^{1}$ University of Tunis, High Institute of Management, GEF-2A Lab, Tunis, Tunisia \\ ${ }^{2}$ La Rochelle Business School, IRGO, France \\ Correspondence: Rim Boussaada, University of Tunis, High Institute of Management, GEF-2A Lab, Tunis, \\ Tunisia. Tel: 216-9862-8084. E-mail: boussaada.r@gmail.com
}

Received: January 12, 2015

Accepted: February 4, 2015

Online Published: March 25, 2015

doi:10.5539/ijef.v7n4p46

URL: http://dx.doi.org/10.5539/ijef.v7n4p46

\begin{abstract}
This paper examines the impact of board of directors on the variability of bank performance in the Middle East and North Africa (MENA) region. Based on a sample of 38 banks during 2004-2011, we examine the impact of board characteristics on performance. Our results show that as the size of a bank's board of directors decreases its performance increases. However, the presence of CEO duality, independent and institutional directors in the board of directors is not significant in explaining performance differences between MENA banks. In addition, the results highlight the fact that state directors undermine the performance while foreign directors are relevant to strengthen the performance in MENA banks. Indeed, our findings highlight the importance of foreign members in enhancing banks performance.
\end{abstract}

Keywords: banks, board structure, performance, MENA

\section{Introduction}

The late 2000s financial crisis has highlighted the critical importance of sound corporate governance for banking organizations. According to Nout Welling (Note 1), ex-president of the Basel committee and the Netherlands Bank, the crisis has highlighted the importance of good governance in the banking system. In this vein, the Basel committee on banking supervision has advocated the need to understand and improve the corporate governance in the financial entities. The committee believes that effective corporate governance practices are necessary to achieving and maintaining public trust and confidence in the banking system, which are critical to the proper functioning of the banking sector and economy as a whole. The board of directors has a crucial role in managing and controlling the activity of the banks. It is considered as a mechanism which allows the resolution of agency problems arising from the separation between ownership functions and decision-making. Good corporate governance standards are imperative to every bank and important to investors and other stakeholders (Al-Amarneh, 2014). The bank board is even more important as a governance mechanism than its non-bank counterparts (Pathan, 2009) because directors solely serve the shareholders, depositors and regulators (Macey \& O'Hara, 2003). The divergence of interests between managers, shareholders and depositors-may surface. Consequently, monitor managers' behavior is necessary. In this context, Ultimate responsibility is typically placed with the board of directors (Macey and O'Hara, 2003; Datar, 2004; Levine, 2004). Bank board's play an important role in bank governance, either monitoring managers or advising them in the design and implementation of strategies (Andres \& Vallelado, 2008). Thus, the bank board structure is relevant to bank performance (Adams \& Mehran, 2008; Andres \& Vallelado, 2008; Pathan, 2009).

There is a little research effort devoted to investigating the effect of board characteristics on banks performance in MENA region as most empirical studies are focused on American, European and Asian countries (Pi \& Timme, 1993; Belkhir, 2009; Staikouras et al., 2007; Zulkafli \& Samad, 2007; Adams \& Mehran, 2008; Alexandre \& Bouaiss, 2008; Pathan \& Faff, 2013). Our study focuses on banking governance in MENA countries. This choice is dictated by the role played by banks in the development of this region (Creane et al., 2004).

The contribution of this study is twofold: First, it aims to fill the gap in banking literature by focusing on the banking sector in the MENA region. Indeed, there are few country-level studies that examine the relationship between the board structure and the MENA bank performance (Bektas \& Keymak, 2009 for Turkey; Chahine \& 
Safieddine, 2009 for Lebanon; Trabelsi, 2010; Rachdi \& Ghazouani Ben Ameur, 2011 for Tunisia; Al-Amarneh, 2014 for Jordan). Second, it aims to gain an understanding of a significant determinant, board of directors, which is associated with bank performance by tracing the board structure details of 38 banks in 10 MENA countries. In this paper, we are interested in the governance mechanisms that can influence the performance of MENA banks. We apply a dynamic panel data approach to examine the determinants of performance of banks in MENA region during 2004-2011. Particularly, we focus on the characteristics of the board of directors. We show that board structure is particularly relevant for MENA banks performance. We find that as the size of a bank's board of directors decreases its performance increases. However, the presence of CEO duality, independent and institutional directors on the board are not significant in explaining performance differences between MENA banks. In addition, the results highlight the fact that state directors undermine the performance while foreign directors are relevant to explaining the performance in MENA banks. Indeed, our findings highlight the importance of foreign members in enhancing banks performance.

The remainder of this paper is structured as follows. The second section presents a review of the literature on the topic and presents our hypotheses. The third section investigates the impact of governance on the performance of banks through a study of a sample of MENA banks. We provide the results of our empirical analysis in the fourth section. We conclude in the fifth section.

\section{Related Literature}

For the agency theory, the board of directors has the responsibility to monitor the management decisions (Sumner \& Webb, 2005). However, agency conflicts may exist within the board. Then the board structure seems to influence the performance. In our study we are interested by the size of the board, and the composition of bank's board of directors (CEO/chairman duality, the presence of independent, state, institution and foreign directors)

\subsection{The Board Size}

The principal functions of the board of directors are monitoring and advising managers (Jensen, 1993). The board size is mainly used as indicator of the effectiveness of the board. According to the resource dependence theory (Pfeffer \& Salancik, 1978), large board size facilitates manager monitoring and brings more management skills and experiences that makes it difficult for the CEO to manipulate the board (Zahra \& Pearce, 1989). However, the proponents of agency theory (Jensen, 1993) argue that large board size can lead to problems of coordination, control and flexibility in decision-making because board members can collude with managers to expropriate the other stakeholders. The agency theory predicts that a smaller board should be more effective. The theoretical debate about the impact of board size on the bank's performance is unresolved. The empirical results are also mixed. Staikouras et al. (2007) conclude that there is a statistically significant and negative relationship between the board size and European bank performance. Simpson and Gleason (1999) find no effect of the number of directors on the probability of financial distress. However, Adams and Mehran (2008) identifies a significant positive correlation between board size and bank performance in USA. Andres and Vallelado (2008), based on a sample of 69 large banks in North America and Europe from 1995 to 2005 conclude that the addition of new directors is positively related to bank performance. This result is confirmed by Belkhir (2009a) for American banks. Based on a sample of 212 large American banks over the period 1997-2011, using the system GMM estimation technique, Pathan and Faff (2013) show a strong negative relation between bank board size and performance. Alexandre and Bouaiss (2008) find a negative relationship between the board of 18 French banks from 1998 to 2004 and its performance. Regarding the MENA region, Bektas and Kaymak (2009) indicate that board size do not significantly influence the returns on assets of Turkish banks. Chahine and Safieddine (2009) reports that Lebanon bank performance is positively related to board size. However, Trabelsi (2010) find that the high number of the board's members has a very negative effect over performance of a sample of 10 Tunisian banks during the period 1997-2007. Based on a sample of 11 large Tunisian commercial banks during 1997-2006, Rachdi and Ghazouani Ben Ameur (2011) find that a small bank board is associated with more performance. Recently, Al-Amarneh (2014) study a sample of 13 listed banks in Jordan during 2000-2012 and find that as board size increases the bank performance increase. In our study, we expect a positive association between board size and bank performance:

\section{H1: There is a positive relationship between board size and banks' performance.}

\subsection{The CEO Duality}

CEO duality refers to a situation where the CEO and the Chairman of the board are the same person. The duality is likely to influence the independence of the board of directors (Fama \& Jensen, 1983) and provide more power to the CEO (Boyd, 1995). The board of directors is most effective in its task of control when both these duties 
are separated (Beatty \& Zajac, 1994). The agency theory has emphasized the need to separate the positions of CEO and board chairman to guarantee the board independence and improve the firm transparency (Jensen, 1993). The concentration of power can exacerbate potential conflicts of interest and decrease the effectiveness of monitoring as it restricts the information flow to other board directors and hence reduces board's independent oversight of manager (Fama \& Jensen, 1983; Jensen, 1993). The empirical evidence on the relationship between CEO duality and bank performance is insufficient. Pi and Timme (1993) conclude that American banks with a dual CEO underperform banks where CEO and chairman of the board are two different persons. However, Fogelberg and Griffith (2000) find that the duality does not have any impact on the bank performance. In the MENA countries, Bektas and Kaymak (2009) reveal no performance differences between Turkish banks with duality and nonduality structures. Al-Amarneh (2014) asserts that the CEO duality is positively related to the performance of Jordan bank but the relationship is statistically insignificant. In our study, we expect a positive association between CEO duality and bank performance:

\section{H2: There is a positive relationship between CEO Duality and banks' performance.}

\subsection{Independent Directors}

For the agency theory, independent directors have an incentive to act as monitors of management because they want to protect their reputations as effective and independent decision makers (Fama \& Jensen, 1983). More independent directors are considered to be important element of an effective board (Yermack, 1996; Fama \& Jensen, 1983). However, the presence of independent directors can makes the exchange of information within the board more difficult because they prevent bank managers with specific knowledge from joining the board (Adams \& Ferriera, 2007; Andres \& Vallelado, 2008). Indeed, executive directors facilitate the transfer of information between board members and managers (Adams \& Ferreira, 2007; Coles et al., 2008). In the banking sector, The Basel committee recommends that banks establish boards that are composed of an effective number of directors capable of exercising judgment that are independent of the views of management, large shareholders and governments (BIS, 2006). Regarding the presence of independent directors, many authors find no significant relation between the degree of board independence and performance (Pi \& Timme, 1993; Griffith et al., 2002; Choi \& Hasan, 2005; Adams \& Mehran, 2008). Also, Simpson and Gleason (1999) conclude that independent directors do not influence the probability of American banks. However, Alexandre and Bouaiss (2008) and Andres and Vallelado (2008) observe a positive relation between the proportion of independent directors and performance. Pathan and Faff (2013) find evidence that US banks in which boards have more independent directors perform worse. The analysis of Bektas and Kaymak (2009) reveals a curvilinear relationship with Turkich banks' performance, implying that boards composed of a majority of either insiders or outsiders enjoy high performance. Besides, Chahine and Safieddine (2009) find that ROA and ROE first decrease and then increase with the percentage of outside directors on the Lebanon board. Rachdi and Ghazouani Ben Ameur (2011) conclude that the presence of independent directors within the board affects negatively the performance of Tunisian banks. Hence, we formulate the following hypothesis:

\section{H3: The proportion of independent directors is positively related to banks' performance.}

\subsection{State Directors}

According to the social welfare theory (Atkinson \& Stiglitz, 1980), state-owned banks contribute to economic development and improve the general wealth (Stiglitz, 1993). Indeed, they finance risky projects and grant loans to SMEs in order to encourage investment and improve economic development (Salas \& Saurina, 2002). However, according to the political theory (Shleifer \& Vishny, 1994), State ownership politicizes the resource allocation and can thus block economic development. Public banks are more vulnerable than private banks, to the political lobbies engaged by the various interest groups (Hu et al., 2004). Whatever the theoretical argument, the empirical literature conclude that state-owned banks are less efficient and highly exposed to risk because they finance risky projects, according to the argument of social welfare (Iannotta et al., 2007) and are very vulnerable to political lobbying, according to the political argument (Hu et al., 2004; Sapienza, 2004; Khwaja \& Mian, 2005). Nevertheless, the empirical studies about the role of the director representing the state on bank performance are almost nonexistent. In our study we expect a negative relationship between the proportion of state representing the state and bank performance. In this vein, we formulate the following hypothesis:

H4: the proportion of state directors has a negative impact on banks' performance.

\subsection{The Presence of Institutional Directors}

Although the role of institutional investors in non-financial firms has been subject to much attention from researchers, studies on banking institutions are rare. Are institutional investors active or passive in the banking 
governance? The few existing studies cannot give a clear response. The proponents of the activism theory refer to the agency theory teachings and argue that institutional investors are more conscious and more competent than the other shareholders (Pearce \& Zahra, 1992). However, advocates of the passivity theory argue that institutional investors are supposed to play a passive role in bank governance. The institutional investors' control is weaker in banks than in other firms because of regulation, which appears to be a substitute of the monitoring carried out by institutional shareholders (Adams \& Mehran, 2003; Elyasiani \& Jia, 2008). The institutional director can effectively control the bank activity. He has the skills, the knowledge and the experience that are appropriate in order to effectively control the management decisions. We therefore formulate the following hypothesis:

\section{H5: the proportion of institutional directors has a positive impact on the performance of MENA banks.}

\subsection{The Presence of Foreign Directors}

The liberalization of capital markets has facilitated the opening of the banks' capital to foreign investors. The acquisition of local banks through the privatization policies or the establishment of subsidiaries is the main catalyst of foreign investors' implementation mainly from foreign banks. Foreign participation in a bank's capital appears to be a signal of "good governance" (Gulamhussen \& Guerriero, 2009). In the presence of a foreign director, the board can exercises its disciplinary function more efficiently. Indeed, the foreign director is even much more independent (Gulamhussen \& Guerriero, 2009) and more experienced than the other directors (Choi \& Hasan, 2005). In this context, Berger et al. (2000) developed two hypotheses: The home field advantage hypothesis and the global advantage hypothesis. Under the home field advantage hypothesis, domestic institutions are generally more efficient than foreign institutions. The banks controlled by foreigner may suffer from difference in language, culture and regulatory and supervisory structures. Thus, the domestic owned banks have some comparative advantage that foreign owned banks lack. Under the global advantage hypothesis, foreign institutions can overcome cultural and institutional barriers and operate more efficiently than domestic ones. Regarding the empirical studies, Choi and Hasan (2005) find a significant effect of the presence of foreign member in the board of director on bank return and risk. We formulate the following hypothesis:

H6: The proportion of foreign directors is positively related to banks 'performance.

\section{Empirical Methodology}

\subsection{Variables Used}

We measure bank performance by using the Return on Assets (ROA) which is an accounting measure, and the Return on Equity $(R O E)$ which is a stock measure. Many others studies use these measures as the dependant variable in research on board effectiveness (Andres \& Vallelado, 2008). The board characteristics include the size of the board, the composition of the bank's board of directors. We include board size $(B S)$ as the number of directors in the board. A dummy variable (Dual) is used to capture the independency of the board. Dual is equals one if the Chief Executive Officer also serves as chairperson of the board, zero otherwise. We take into account also the percentage of total directors who are independent (Ind). We include three other variables concerning the composition of the board. Institutional director (Instit) is defined as the percentage of total directors who represent institutional investors. State directors (Stat) is measured as the percentage of total directors who represent the state. Finally, we calculate the percentage of foreign directors to total directors on the board (Frg). A first group of control variables measures differences in bank structure. We take into account the bank size (Size), Charter value (Charter) and bank capital (Capital). Our second group of control variables accounts for the differences among MENA countries in terms of economic growth and institutional environment. To control for economic expansion we use the GDP Growth $(G D P g r)$. To account for the differences in the institutional quality amongst countries, we include the Institutional quality $(I Q)$ which is the Regulatory Quality indicator produced by Kaufmann et al. (2010). Moreover, we include year dummies to capture year effect.

Table 1 shows the data source and a brief description of our key variables used in this study. 
Table 1. Summary of the variables

\begin{tabular}{|c|c|c|}
\hline Variables & Definition & Data Source \\
\hline Performance & $\begin{array}{l}\text { ROA: ratio of net income to total assets } \\
\text { ROE: ratio of net income to total equity }\end{array}$ & Bankscope \\
\hline BS & $\begin{array}{l}\text { The number of directors in the bank's board (Simpson and Gleason, 1999; Sumner and } \\
\text { Webb, 2005; Pathan, 2009) }\end{array}$ & Annual report of banks \\
\hline Dual & $\begin{array}{l}\text { Dummy variable which equals one if the Chief Executive Officer also serves as } \\
\text { chairperson of the board, zero otherwise. (Simpson and Gleason, 1999; Pathan, 2009; } \\
\text { Palvia, 2011) }\end{array}$ & Annual report of banks \\
\hline Ind & $\begin{array}{l}\text { The percentage of total directors who are independent (Pathan et al. 2007, Andres and } \\
\text { Vallelado, 2008; Pathan, 2009). }\end{array}$ & Annual report of banks \\
\hline Instit & The percentage of total directors who represent institutional investors & Annual report of banks \\
\hline Frg & $\begin{array}{l}\text { The percentage of foreign directors to total directors on the board (Choi et Hasan, 2005; } \\
\text { Gulamhussen and Guerreiro,2009). }\end{array}$ & Annual report of banks \\
\hline Stat & The percentage of total directors who represent the state (Konishi and Yasuda, 2004) & Annual report of banks \\
\hline Size & $\begin{array}{l}\text { The natural logarithm of total assets (Pathan et al., 2007; Pathan, 2009; Azofra and } \\
\text { Santamaria, 2011) }\end{array}$ & Bankscope \\
\hline NPLs & $\begin{array}{l}\text { Non-performing loans/ total loans(Gonzalez, 2005; Salas and Saurina,2002; Shehzad et } \\
\text { a.l 2010) }\end{array}$ & Bankscope \\
\hline Capital & The bank total equity as percentage of total assets (Iannotta et al. 2007; Pathan, 2009) & Bankscope \\
\hline Charter & $\begin{array}{l}\text { Keeley's Q (Keeley, 1990) which is calculated as the sum of the market value of equity } \\
\text { plus the book value of liabilities divided by the book value of total assets. }\end{array}$ & Bankscope \\
\hline GDP_gr & Growth rate of gross domestic product on annual basis & $\begin{array}{l}\text { World development } \\
\text { indicators of the World } \\
\text { Bank }\end{array}$ \\
\hline IQ & $\begin{array}{l}\text { Institutional quality measured by the variable Regulatory Quality which take into account } \\
\text { the ability of the government to implement policies and regulations that promote private } \\
\text { sector development }\end{array}$ & $\begin{array}{l}\text { World Governance } \\
\text { Indicators compiled by } \\
\text { Kaufmann et al. }(2010)\end{array}$ \\
\hline Year & $\begin{array}{l}7 \text { individual dummy variables which equals either one or zero for each year from } 2004 \text { to } \\
2011 \text { with } 2004 \text { being the excluded year }\end{array}$ & Authors \\
\hline
\end{tabular}

\subsection{Methodology}

We use the following regression model to examine the board characteristics on the performance of MENA banks.

$$
\text { Performance }_{i, t}=f\left(\text { board }_{\text {characteristics }}{ }_{i, t} \text {, control } \text { variables }_{i, t}\right)+\varepsilon t_{i, t}
$$

The index $\mathrm{i}$ denotes the bank $(\mathrm{i}=1, \ldots, 38)$, whereas the index $(\mathrm{t})$ denotes the year under consideration $(\mathrm{t}=2004, \ldots, 2011)$.

In our study, we apply a dynamic panel data approach. Indeed, the characteristics of board are endogenously determined by firm performance (Hermalin \& Weisbach, 2003). In this respect, the cross-sectional Ordinary Least Square (OLS) regressions of bank performance on single governance mechanisms may be misleading (Belkhir, 2009b). To address the endogeneity problem, we use the System Generalized Method of Moments (SGMM) estimators developed by Arellano and Bover (1995) and Blundell and Bond (1998). The SGMM simultaneously takes into account the unobserved heterogeneity, the endogeneity and the heteroskedasticity of the explanatory variables for panel data (Andres \& Vallelado, 2008). Also, the SGMM allows us to solve the problem of simultaneity between the ownership structure and corporate value (Demsetz \& Villalonga, 2001). Like Azofra and Santamria (2011) and since our sample size is not very large, we use the procedure suggested by Windmeijer (2005) that improves the robustness of our results. The lagged levels of explanatory variables are used as instruments. To test model specifications validity, we use the Sargan test of over-identifying restrictions that checks the validity of the instruments. We also include the $\operatorname{AR}(1)$ and $\operatorname{AR}(2)$ to test the first and second-order serial correlation, respectively. 


\section{Results}

4.1 Descriptive Statistics

Table 2. Descriptive statistics

\begin{tabular}{|c|c|c|c|c|}
\hline \multicolumn{5}{|c|}{ Continuous variables } \\
\hline Variables & Mean & Min & Max & SD \\
\hline ROA & 0.10 & -0.10 & 3.49 & 0.44 \\
\hline ROE & 0.13 & -1.11 & 0.79 & 0.13 \\
\hline BS & 10.27 & 5 & 15 & 1.73 \\
\hline Ind & 0.21 & 0 & 0.7 & 0.23 \\
\hline Instit & 0.30 & 0 & 0.8 & 0.23 \\
\hline Frg & 0.22 & 0 & 0.7 & 0.22 \\
\hline Stat & 0.09 & 0 & 0.58 & 0.15 \\
\hline Size & 15.88 & 11.58 & 19.65 & 1.79 \\
\hline NPLs & 10.70 & 0.21 & 47.89 & 9.63 \\
\hline Capital & 0.11 & 0.03 & 0.25 & 0.04 \\
\hline Gdp_gr & 0.05 & -0.01 & 0.20 & 0.04 \\
\hline Charter & 0.92 & 0.74 & 1.26 & 0.08 \\
\hline IQ & 0.10 & -0.49 & 0.83 & 0.32 \\
\hline \multicolumn{5}{|c|}{ Dummy variables: } \\
\hline \multirow{3}{*}{ Dual } & \multicolumn{3}{|c|}{ Modality } & Frequency \\
\hline & \multicolumn{3}{|c|}{ 1: Duality of leadership } & $33.22 \%$ \\
\hline & \multicolumn{3}{|c|}{0 : dissociation of leadership } & $66.77 \%$ \\
\hline
\end{tabular}

The descriptive statistics are presented in Table 2. In particular the average of ROA and ROE is 0.10 and 0.13 respectively. On average, the MENA banks of our sample have 10 members on their board. With respect of the board composition, the presence of institutional directors appears to be higher than foreign and state directors. We note that in the majority of MENA banks there is a separation of the functions of decision and control. In $33 \%$ of banks in the sample, the Chief executive Officer presided at the board. The Pearson's correlation matrix (Appendix, table I) indicates that the degree of correlation between variables is low which suggests the absence of multicollinearity problem in the models.

\subsection{Multivariate Analysis}

Table 3 presents the results from the regressions of board structure variables and control variables on our performance measure. According to the table, the models seem well-fitted with statistically significant test statistics for second-order autocorrelation in the first difference (AR1), and statistically insignificant test statistics in the second difference (AR2). Likewise, we confirm the validity of the instruments using the Sargan over-identification test. In all models, the statistically insignificant Sargan test indicates that instruments are valid in the estimations.

Table 3. Board of directors and bank performance

\begin{tabular}{lll}
\hline Independent variables & ROA & ROE \\
& Model 1 Coeff. $(\mathrm{t})$ & Model 2 Coeff. $(\mathrm{t})$ \\
\hline Constant & $0.082(0.435)$ & $0.075(0.681)$ \\
ROA $(-1)$ & $0.653(50.36)^{* * *}$ & - \\
ROE $(-1)$ & - & $0.353(43.851)^{* * *}$ \\
BS & $-0.005(-1.726)^{*}$ & $-0.010(-4.446)^{* * *}$ \\
Dual & $0.002(0.160)$ & $-0.009(-0.881)$ \\
Ind & $0.015(0.453)$ & $0.004(0.222)$ \\
Stat & $-0.095(-1.679)^{*}$ & $-0.055(-0.693)$ \\
Instit & $0.005(0.142)$ & $0.022(1.311)$ \\
Foreign & $0.049(1.236)$ & $0.055(3.374)^{* * *}$ \\
Size & $0.007(1.764)^{*}$ & $0.009(3.369)^{* * *}$ \\
\hline
\end{tabular}




\begin{tabular}{lll}
\hline Capital & $0.524(1.990)^{* *}$ & $0.893(5.276)^{* * *}$ \\
NPLs & $-0.299(-2.599)^{* * *}$ & $-0.318(-7.017)^{* * *}$ \\
Charter & $-0.078(-0.703)$ & $-0.156(-2.398)^{* *}$ \\
GDP_gr & $0.119(0.884)$ & $0.137(2.310)^{* *}$ \\
IQ & $0.044(2.364)^{* *}$ & $0.033(2.607)^{* * *}$ \\
year dummies & Yes & Yes \\
Observations & 254 & 257 \\
Sargan test & $9.361(0.99)$ & $22.569(0.65)$ \\
AR(1) & $-1.727(0.08)^{* *}$ & $-1.999(0.04)^{* *}$ \\
AR(2) & $-0.894(0.37)$ & $-0.909(0.36)$ \\
N of instruments & 47 & 46 \\
\hline
\end{tabular}

Note. All variables are defined in table 1. The dependent variables are the ROA in model (1) and the ROE in model (2). AR (1) and AR (2) are t-statistics for first and second order serial correlation. Sargan is a test of the over-identifying restrictions under the null that the instruments are valid. The right-hand side variables are treated as endogenous using lags back from $\mathrm{t}-2$ as instruments. $* \mathrm{p}<0.01 ; * * \mathrm{p}<0.05$; $* * * \mathrm{p}<0.001$.

With the regard to the board size, the coefficient of $B S$ is negative and significant across the two measures of performance. These results suggest that the addition of new directors in MENA bank's board undermine the performance of banks. Our result confirms the findings of Staikouras et al. (2007) for a panel of Europeans banks and contradicts those of Adams and Mehran (2005) for American banks. Our result is consistent with the agency theory hypothesis. Regarding the CEO duality, the results indicate that the coefficient of Dual is statistically insignificant. Our hypothesis is then not confirmed. We conclude that CEO duality do not affect the MENA bank's performance. Our result refutes the empirical evidence of Simpson and Gleason (1999) and Pathan (2009) for a panel of Americans banks. However, our findings corroborate the results Bektas and Kaymak (2009) and Al-Amarneh (2014) for Turkish and Jordan banks. We explain this result by the relative variability of the leadership structure of the board during the sample period which makes it difficult to identify the impact of duality on performance. Besides, the coefficient of Ind is statically insignificant. We conclude that the presence of independent members on MENA board don't affect the performance of banks. Even when MENA boards contain independent members, the latter cannot counter-balance the other stakeholders' interests. In MENA region, banks were required to increase their number of independent board members irrespective of their performance. Consistent with the expectations, the coefficient on Stat is negative and statically significant for only ROA. This illustrates that the economic performance of MENA banks is deteriorated with the presence of a state directors in the board. Our finding about the statistically insignificant coefficient STAT for ROE point to clear evidence that the financial performance of banks is not affected by the state directors on the board. In fact, in MENA region, there is no clear system of accountability or responsibility for performance of government-appointed board members or executive management (Rochat et al., 2011). Also, results show that institutional directors (Instit) do not affect performance in the MENA countries. We conclude that an institutional director don't impact banks performance. Indeed, bank board in MENA lack knowledge and experience to challenge management in evolving risk profiles of borrowers (Rochat et al., 2011). Regarding the presence of foreign directors on the board, results show that the coefficient $(\mathrm{Frg})$ is positive and statically significant for only ROE. We explain this result by the superior managerial skills and experience of foreign directors which translate into an improvement in MENA financial performance. Thus, we confirm the global advantage hypothesis of Berger et al. (2000). In most regressions, the bank size explains the variation of performance. Our finding indicates that the size of banks (Size) is significant and positive. It appears that large banks, due to the economies of scale, have the experience and the necessary resources to properly monitor managers and increase the performance. Our results reveal that bank capital has a significant positive impact on performance. Furthermore, the charter value banks have a significant and negative impact on their performance. Banks with high charter value are associated with higher ROA and ROE. Besides, GDP growth exhibits positive and statistically significant relationship in all regression models. We conclude that the economic growth ameliorate the financial sector performance in MENA region. Also, credit risk is significant exhibiting negative relationship with performance measure. Finally, we notice that the coefficient on institutional quality variable $(I Q)$ is significant and positive in all regressions.

\subsection{Robustness Chek}

In order to test the sensitivity of estimation results, we use alternative proxies for some of the variables. We first use the Market to Book ratio as an alternative proxy for the bank performance. The results obtained remain the 
same. In terms of institutional quality, we replace the regulatory quality by the others five dimensions of governance provided by Kaufman et al. (2010). We include simultaneously, voice and accountability as indicator of the extent of political and civil rights; political instability and violence which indicates the likelihood of violent threats or changes in governments; government effectiveness which measures the competence and the quality of public service delivery; regulatory burden which measures the incidence of market unfriendly policies; and finally control of corruption as a proxy of the exercises of public power for private gain, including both soft and grand corruption and state capture. The results remain similar without many changes.

\section{Conclusion}

The aim of this paper was the study of board of director's characteristics on performance for a sample of MENA banks. Through a dynamic panel data approach and after controlling for the endogeneity problem we establish relationship between banks' performance and three main attributes of board: the board size, the presence of state directors and foreign directors. However, the presence of CEO duality, independent and institutional directors on the board are not significant in explaining performance differences between MENA banks. We conclude that the board of directors plays an effective role in bank governance. With these different results, our research could provide some policy implications. Indeed, the board of directors is the primary mechanism of the internal control system, serving to discipline and monitor managers and MENA countries need to take effective measures to improve the functioning of this mechanism. Although large board may reflect more variety in experience and knowledge, the board must be composed by few directors who cannot be manipulated by managers. Besides, MENA Bank board's lack the presence of independent members. Moreover, even in the cases where the presence of these members is reported, they are passive and their independence is not confirmed and subject to conversers.

Further investigations are needed to better apprehend the impact of bank board characteristics and this respective impact on bank performance. For instance, it is worthy to incorporate other board characteristics as the nature and the composition of the committees connected with it and the members' remuneration.

\section{Acknowledgements}

Dr. Boussaada and Dr. Karmani aknowledge the editor and the external reviewer of the International Journal of Economic and Finance for useful comments.

\section{References}

Adams, R., \& Mehran, H. (2003). Is corporate governance different for bank holding companies? Economic Policy Review - Federal Reserve Bank of New York, 9, 123-142.

Adams, R., \& Ferreira, D. (2007). A theory of friendly board. Journal of Finance, 62, 217-250. http://dx.doi.org/10.1111/j.1540-6261.2007.01206.x

Adams, R., \& Mehran, H. (2008). Corporate performance, board structure and its determinants in the banking industry. Federal Reserve Bank of New York, Staff Reports n 330.

Al-Amarneh, A. (2014). Corporate governance, ownership structure and bank performance in Jordan. International Journal of Economics and Finance, 6(6), 192-202. http://dx.doi.org/10.5539/ijef.v6n6p192

Alexandre, H., \& Bouaiss, K. (2008). The complementary of regulatory and internal governance mechanisms in banks. Bankers, Markets \& Investors, 98, 1-10.

Arellano, M., \& Bover, O. (1995). Another look at the instrumental variable estimation of error-components models. Journal of Econometrics, 68, 29-51. http://dx.doi.org/10.1016/0304-4076(94)01642-D

Andres, P., \& Vallelado, E. (2008). Corporate governance in banking: The role of the board of directors. Journal of Banking and Finance, 32, 2570-2580. http://dx.doi.org/10.1016/j.jbankfin.2008.05.008

Atkinson, A. B., \& Stiglitz, J. E. (1980). Lectures on Public Economics. New York: Mc-Graw Hill.

Azofra, V., \& Santamaria, M. (2011). Ownership, control, and pyramids in Spanish commercial banks. Journal of Banking and Finance, 35, 1464-1476. http://dx.doi.org/10.1016/j.jbankfin.2010.10.029

Bank for International Settlements. (2006). Enhancing corporate governance for banking organisations. Discussion Paper, Basel Committee on Banking Supervision, Basel.

Beatty, R. P., \& Zajac, E. J. (1994). Top management incentives, monitoring, and risk sharing: A study of executive compensation, ownership and hoard structure in initial public offerings. Administrative Science Quarterly, 39, 313-336. http://dx.doi.org/10.2307/2393238

Bektas, E., \& Kaymak, T. (2009). Governance mechanisms and ownership in an emerging market: The case of 
Turkish banks. Emerging Markets Finance and Trade, 45(6), 20-32. http://dx.doi.org/10.2753/REE1540-496X450602

Belkhir, M. (2009a). Board of Directors' Size and Performance in the Banking Industry. International Journal of Managerial Finance, 5(2), 201-221. http://dx.doi.org/10.1108/17439130910947903

Belkhir, M. (2009b). Board structure, ownership structure and firm performance: Evidence from banking. Applied Financial Economics, 19, 1581-1593. http://dx.doi.org/10.1080/09603100902967561

Berger, A. N., De Young, R., Genay, H., \& Udell, G. F. (2000). The globalization of financial institutions: Evidence from cross-border banking performance. Brookings-Wharton Papers on Financial Services, 3, 23-158. http://dx.doi.org/10.1353/pfs.2000.0001

Blundell, R., \& Bond, S. (1998). Initial Conditions and Moment Restrictions in Dynamic Panel Data Models. Journal of Econometrics, 87, 115-143. http://dx.doi.org/10.1016/S0304-4076(98)00009-8

Boyd, B. K. (1995). CEO duality and firm performance: A contingency model. Strategic Management Journal, 16(4), 301-312. http://dx.doi.org/10.1002/smj.4250160404

Chahine, S., \& Safieddine, A. (2009). Is Corporate Governance Different For The Lebanese Banking System? Journal of Management and Governance, 15(2), 207-226. http://dx.doi.org/10.1007/s10997-009-9096-7

Choi, S., \& Hasan, I. (2005). Ownership, Governance, and Bank Performance: Korean Experience. Financial Markets, Institutions \& Instruments, 14, 215-242. http://dx.doi.org/10.1111/j.0963-8008.2005.00104.x

Coles, J. L., Naveen, D. D., \& Naveen, L. (2008). Boards: Does one size fit all? Journal of Financial Economics, 87, 329-356. http://dx.doi.org/10.1016/j.jfineco.2006.08.008

Creane, G., Goyal, R., Mobarak, M., \& Sab, R. (2004). Financial sector development in the Middle East and North Africa. IMF Working Paper WP/04/201.

Datar, M. K. (2004). Corporate governance in financial intermediaries. Economic and Political Weekly, 39(4), 328-332.

Demsetz, H., \& Villalonga, B. (2001). Ownership structure and corporate performance. Journal of Corporate Finance, 7, 209-233. http://dx.doi.org/10.1016/S0929-1199(01)00020-7

Elyasiani, E., \& Jia, J. J. (2008). Institutional ownership stability and BHC performance. Journal of Banking and Finance, 32, 1767-1781. http://dx.doi.org/10.1016/j.jbankfin.2007.12.010

Fama, E., \& Jensen, M. C. (1983). Separation of Ownership and Control. Journal of Law and Economics, 88(2), 301-325. http://dx.doi.org/10.1086/467037

Fogelberg, L., \& Griffith, J. M. (2000). Control and bank performance. Journal of Financial and Strategic Decisions, 13(3), 63-69.

Gonzalez, F. (2005). Bank regulation and risk taking incentives: An international comparison of bank risk. Journal of Banking and Finance, 29, 1153-1184. http://dx.doi.org/10.1016/j.jbankfin.2004.05.029

Griffith, J. M., Fogelberg, L., \& Weeks, H. S. (2002). CEO ownership, corporate control, and bank performance. Journal of Economics and Finance, 26, 170-183. http://dx.doi.org/10.1007/BF02755984

Gulamhussen, M. A., \& Guerreiro, L. (2009). The influence of foreign equity and board membership on corporate strategy and internal cost management in Portuguese banks. Management Accounting Research, 20, 6-17. http://dx.doi.org/10.1016/j.mar.2008.10.006

Hermalin, B. E., \& Weisbach, M. S. (2003). Board of directors as an endogenously determined institution: A survey of the economic literature. FRBNY Economic Policy Review, 7-26.

Hu, J. L., Li, Y., \& Chiu, Y. H. (2004). Ownership and Non-performing Loans: Evidence from Taiwan's Banks. Developing Economies, 42(3), 405-420. http://dx.doi.org/10.1111/j.1746-1049.2004.tb00945.x

Iannotta, G., Nocera, G., \& Sironi, A. (2007). Ownership structure, risk and performance in the European banking industry. Journal of Banking and Finance, 31, 2127-2149. http://dx.doi.org/10.1016/j.jbankfin.2006.07.013

Jensen, M. (1993). The modern industrial revolution, exit and the failure of internal control systems. Journal of Finance, 48(3), 831-880. http://dx.doi.org/10.1111/j.1540-6261.1993.tb04022.x

Kaufmann, D., Kraay, A., \& Mastruzziet, M. (2010). The Worldwide Governance Indicators: Methodology and Analytical Issues. World Bank Policy Research Working Paper n 5430. 
Keeley, M. C. (1990). Deposit insurance, risk and market power in banking. The American Economic Review, 80, 1183-1200.

Khwaja, A. I., \& Mian, A. (2005). Do Lenders Favor Politically Connected Firms? Rent Provision in an Emerging Financial Market. Quarterly Journal of Economics, 120(4), 1371-1411. http://dx.doi.org/10.1162/003355305775097524

Konishi, M., \& Yasuda, Y. (2004). Factors affecting bank risk taking: Evidence from Japan. Journal of Banking and Finance, 28, 215-232. http://dx.doi.org/10.1016/S0378-4266(02)00405-3

Levine, R. (2004). The Corporate Governance of Banks: A Concise Discussion of Concepts and Issues. World Bank Policy Research Working Paper $n 3404$.

Macey, J. R., \& O'Hara, M. (2003). The corporate governance of banks. FRBNY Economic Policy Review, 9, 91-107.

Palvia, A. A. (2011). Banks and managerial discipline: Does regulatory monitoring play a role? The Quarterly Review of Economics and Finance, 51, 56-68. http://dx.doi.org/10.1016/j.qref.2010.10.003

Pathan, S., Skully, M., \& Wickramanayake, J. (2007). Board size, independences and performance: An analysis of Thai banks. Asia-Pacific Financial Markets, 14, 211-227. http://dx.doi.org/10.1007/s10690-007-9060-y

Pathan, S. (2009). Strong boards, CEO power and bank risk-taking. Journal of Banking and Finance, 33 , 1340-1350. http://dx.doi.org/10.1016/j.jbankfin.2009.02.001

Pathan, S., \& Faff, R. (2013). Does Board Structure in Banks Really Affect their Performance? Journal of Banking \& Finance, 37, 1573-1589. http://dx.doi.org/10.1016/j.jbankfin.2012.12.016

Pearce, J. A., \& Zahra, S. A. (1992). Board composition from a strategic contingency perspective. Journal of Management Studies, 29, 411-438. http://dx.doi.org/10.1111/j.1467-6486.1992.tb00672.x

Pfeffer, J., \& Salancik, G. R. (1978). The External Control of Organizations: A Resource Dependence Perspective. Harper et Row, New York.

Pi, L., \& Timme, S. (1993). Corporate Control and Bank Efficiency. Journal of Banking and Finance, 17, 515-530. http://dx.doi.org/10.1016/0378-4266(93)90050-N

Rachdi, H., \& Ghazouani Ben Ameur, I. (2011). Board Characteristics, Performance and Risktaking Behaviour in Tunisian Banks. International Journal of Business and Management, 6(6), 88-97. http://dx.doi.org/10.5539/ijbm.v6n6p88

Rochat, R. R., Arvai, Z., \& Farazi, S. (2011). Financial Access and Stability: A Road Map for the Middle East and North Africa. The World Bank Report.

Salas, V., \& Saurina, J. (2002). Credit risk in two institutional regimes: Spanish Commercial and Savings banks. Journal of Financial Services Research, 22(3), 203-224. http://dx.doi.org/10.1023/A:1019781109676

Sapienza, P. (2004). The Effects of Government Ownership on Bank Lending. Journal of Financial Economics, 72, 357-384. http://dx.doi.org/10.1016/j.jfineco.2002.10.002

Shehzad, C. T., De Haan, J., \& Scholtens, B. (2010). The impact of bank concentration on impaired loans and capital adequacy. Journal of Banking and Finance, 34, 399-408. http://dx.doi.org/10.1016/j.jbankfin.2009.08.007

Shleifer, A., \& Vishny, R. W. (1994). Politicians and Firms. Quarterly Journal of Economics, 109, 995-1025. http://dx.doi.org/10.2307/2118354

Simpson, W. G., \& Gleason, A. E. (1999). Board structure, ownership, and financial distress in banking firms. International Review of Economics \& $\quad$ Finance, $8,281-292$. http://dx.doi.org/10.1016/S1059-0560(99)00026-X

Sumner, S., \& Webb, E. (2005). Does corporate governance determine bank loan portfolio choice? Journal of Academy of Business and Economics.

Staikouras, P. K., Staikouras, C. K., \& Agoraki, M. E. K. (2007). The effect of board size and composition on European bank performance. European Journal of Law and Economics, 23, 1-27. http://dx.doi.org/10.1007/s10657-007-9001-2

Stiglitz, J. E. (1993). The role of the state in Financial Markets. Proceedings of the World Bank Annual Conference on Economic Development, Washington D.C. International Bank for Reconstruction and 
Development/World Bank, 19-56.

Trabelsi, M. A. (2010). Governance and performance of Tunisian banks. International Journal of Economics and Finance, 2(3). 189-198.

Yermack, D. (1996). Higher market valuation of companies with a small board of directors. Journal of Financial Economics , 40, 185-212. http://dx.doi.org/10.1016/0304-405X(95)00844-5

Windmeijer, F. (2005). A finite sample correction for the variance of linear efficient two-step GMM estimators. Journal of Econometrics, 126, 25-51. http://dx.doi.org/10.1016/j.jeconom.2004.02.005

Zahra, S. A., \& Pearce, II J. A. (1989). Boards of directors and corporate performance: A review and integrative model. Journal of Management, 15(2), 291-334. http://dx.doi.org/10.1177/014920638901500208

Zulkafli, A. H., \& Samad, F. A. (2007). Corporate governance and performance of banking firms: Evidence from Asian emerging markets. Advances in Financial Economics, 12, 49-74. http://dx.doi.org/10.1016/S1569-3732(07)12003-X

\section{Notes}

Note 1. www.bis.org/press/p100316.htm

Note 2. For all estimations, the Sargan test of over identifying restriction of the instruments has not rejected the null hypothesis of valid instruments.

Appendix A. The Correlation Matrix of Pearson

\begin{tabular}{|c|c|c|c|c|c|c|c|c|c|c|c|c|c|c|}
\hline & ROA & ROE & BS & Dual & Ind & Stat & Frg & Instit & Size & NPLs & Capital & Charter & GDP_gr & IQ \\
\hline ROA & 1 & & & & & & & & & & & & & \\
\hline ROE & 0.06 & 1 & & & & & & & & & & & & \\
\hline BS & 0.08 & $-0.16^{*}$ & 1 & & & & & & & & & & & \\
\hline Dual & $-0.14 *$ & 0.01 & -0.00 & 1 & & & & & & & & & & \\
\hline Ind & $0.18^{*}$ & $0.10^{* *}$ & $-0.30^{*}$ & -0.06 & 1 & & & & & & & & & \\
\hline Stat & $-0.13 *$ & -0.08 & $0.18^{*}$ & $0.34 *$ & $-0.16^{*}$ & 1 & & & & & & & & \\
\hline Frg & -0.05 & 0.02 & 0.09 & $-0.13^{*}$ & $-0.48^{*}$ & $-0.38 *$ & 1 & & & & & & & \\
\hline Instit & -0.00 & -0.05 & $0.28 *$ & $-0.15^{*}$ & $-0.38^{*}$ & $-0.44 *$ & $0.55^{*}$ & 1 & & & & & & \\
\hline Size & $-0.19 *$ & $0.26^{*}$ & $0.10^{* *}$ & $0.15^{*}$ & -0.02 & 0.05 & $0.19^{*}$ & -0.03 & 1 & & & & & \\
\hline NPLs & -0.02 & $-0.32 *$ & $0.13 * *$ & $0.10^{* *}$ & $-0.33^{*}$ & $0.15^{*}$ & 0.05 & $0.13^{*}$ & $-0.39 *$ & 1 & & & & \\
\hline Capital & $0.13^{* *}$ & -0.04 & $-0.27 *$ & $-0.20^{*}$ & $0.32 *$ & $-0.23 *$ & $-0.18^{*}$ & -0.01 & $-0.16^{*}$ & $-0.14 *$ & 1 & & & \\
\hline Charter & $-0.14^{*}$ & -0.05 & 0.02 & $0.31^{*}$ & $-0.33^{*}$ & 0.06 & $0.26^{*}$ & $0.18^{*}$ & $-0.14^{*}$ & $0.16^{*}$ & $-0.49 *$ & 1 & & \\
\hline GDP_gr & 0.03 & $0.10^{* *}$ & -0.09 & $-0.19^{*}$ & $0.24 *$ & -0.09 & $-0.10^{*}$ & 0.09 & 0.09 & $-0.22 *$ & $0.33^{*}$ & $-0.49^{*}$ & 1 & \\
\hline IQ & $0.23^{*}$ & -0.02 & $-0.11^{* *}$ & $-0.41 *$ & $0.34 *$ & 0.01 & $-0.45^{*}$ & $-0.18^{* *}$ & $-0.21 *$ & $-0.26^{*}$ & $0.45^{*}$ & $-0.32 *$ & $0.33^{*}$ & 1 \\
\hline
\end{tabular}

Note. * Statically significant at $5 \%$ level, $* *$ statically significant at $10 \%$ level.

\section{Copyrights}

Copyright for this article is retained by the author(s), with first publication rights granted to the journal.

This is an open-access article distributed under the terms and conditions of the Creative Commons Attribution license (http://creativecommons.org/licenses/by/3.0/). 